\title{
Evidence for a geochemical origin of the mysterious circles in the Pro-Namib desert
}

\author{
Y. Naudé ${ }^{\mathrm{a}, *}$, M.W. van Rooyen ${ }^{\mathrm{b}}$, E.R. Rohwer ${ }^{\mathrm{a}}$ \\ ${ }^{a}$ Department of Chemistry, University of Pretoria, Hatfield, Pretoria 0002, South Africa \\ ${ }^{\mathrm{b}}$ Department of Botany, University of Pretoria, Hatfield, Pretoria 0002, South Africa
}

\section{A R T I C L E I N F O}

\section{Article history:}

Received 8 March 2010

Received in revised form

5 October 2010

Accepted 21 December 2010

Available online $\mathrm{xxx}$

\section{Keywords:}

Fairy circle

Hydrocarbon microseepage

Mima mound (heuweltjies)

Polydimethylsiloxane sorptive extraction

Termites

Vegetation stress

\begin{abstract}
A B S T R A C T
The origin of the so-called "fairy circles" has not yet been established. Carbon monoxide (as an indicator of a natural gas microseep) was monitored inside and outside of the selected fairy circles in the Namib, Namibia, Southern Africa. Hydrocarbons were extracted from the soil by a novel method for trapping analytes onto silicone rubber designed for thermal desorption into a gas chromatograph-mass spectrometer (GC-MS). Unresolved complex mixtures with resolvable alkanes were detected in soil collected from two newly formed circles. Alkenes, the microbial degradation product of alkanes (microbial food source), were more abundant in the circles compared to the levels of alkenes detected in the matrix between circles. Results show a microseepage of gases and hydrocarbons which is expressed at the surface as a geobotanical anomaly of barren circles and circles of altered vegetation. In addition, this finding may suggest a new approach to the origin of the mima mounds (heuweltjies) of the Western Cape in South Africa.
\end{abstract}

(ㄷ) 2010 Elsevier Ltd. All rights reserved.

\section{Introduction}

Traditional Himba folklore holds that beneath the edge of the Namib Desert lies a crack in the earth's crust in which a dragon lives and whenever it exhales bubbles of fire rise to the surface, burning and vaporising the vegetation, forming circles (Carte Blanche, 2004: transcript of televised interview with Dr W. Jankowitz; De Vita, 2006). The origin of the enigmatic pock mark ("fairy circle") patterned landscape of the Namib Desert has fascinated scientists and the general public for many decades. In many arid and semiarid environments around the world striking vegetation patterns have developed (Borgogno et al., 2009; Rietkerk et al., 2004; Van Rooyen et al., 2004). Self-organised vegetative patterns of spots, labyrinths, gaps and stripes can arise in response to competition for limiting water and nutrients (Rietkerk et al., 2004). Spots are small round-shaped clusters of vegetation interspersed within a bare soil background while gaps are round-shaped bare soil islands surrounded by homogeneous vegetation (Borgogno et al., 2009). Currently there is no scientifically sound explanation as to the

\footnotetext{
* Corresponding author. Department of Chemistry, Natural Sciences 1, Room 2.19, University of Pretoria, Hatfield, Pretoria 0002, South Africa. Tel.: +27 12420 2517; fax: +27124204687 .

E-mail addresses: yvette.naude@up.ac.za (Y. Naudé), gretel.vanrooyen@up.ac.za (M.W. van Rooyen), egmont.rohwer@up.ac.za (E.R. Rohwer).
}

cause of fairy circles: circular depressions (Fig. 1a and b) (Jankowitz et al., 2008) which are devoid of vegetation and are often surrounded by a fringe of tall grasses (Van Rooyen et al., 2004). These circles occur in a broken belt in the Pro-Namib zone of the west coast of southern Africa, approximately between 60 and $120 \mathrm{~km}$ inland, extending from southern Angola through Namibia to just south of the Gariep (Orange) River in South Africa (Van Rooyen et al., 2004).

The first reference to the fairy circles was in 1971 when Tinley proposed that the circles were the remains of fossil termitaria (Van Rooyen et al., 2004). In 1978 a group of researchers from the University of Pretoria began investigating the origin of the mysterious circles (Theron, 1979). Eicker et al. (1982) reported on a microbiological study of the barren circles in the Giribes Plain, but did not explain their origin. Theories as to the cause of these circles were related to termite activity, to localised radioactivity and to allelopathic compounds released by dead Euphorbia damarana plants, none of which provided conclusive evidence (Van Rooyen et al., 2004). According to Becker (2007) the foraging behaviour of harvester ants and harvester termites are the prime causal factor for the development of fairy circles under certain conditions. The fairy circles have been linked to the mima mounds ("heuweltjies") of the Southern and Western Cape in South Africa (Albrecht et al., 2001; Lovegrove, 1993). These mounds are believed to be ancient termite nests. As the calculated dispersion indices for mounds and circles were remarkably 


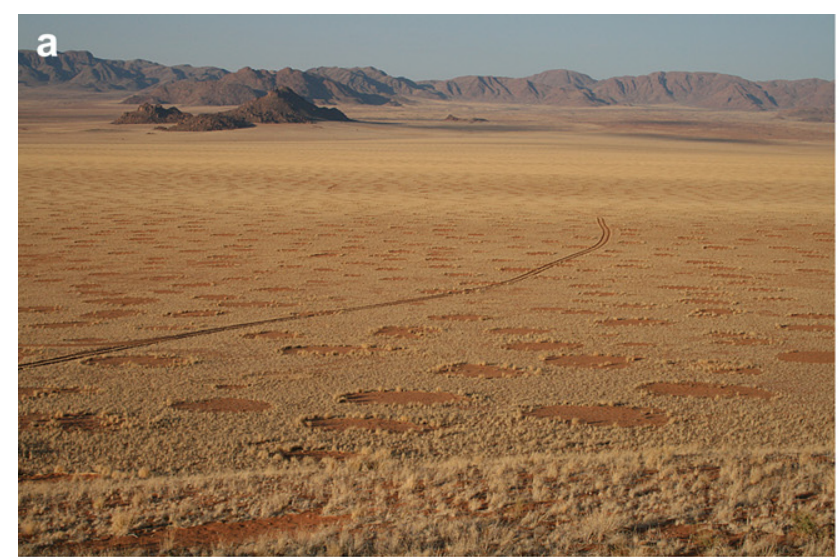

c

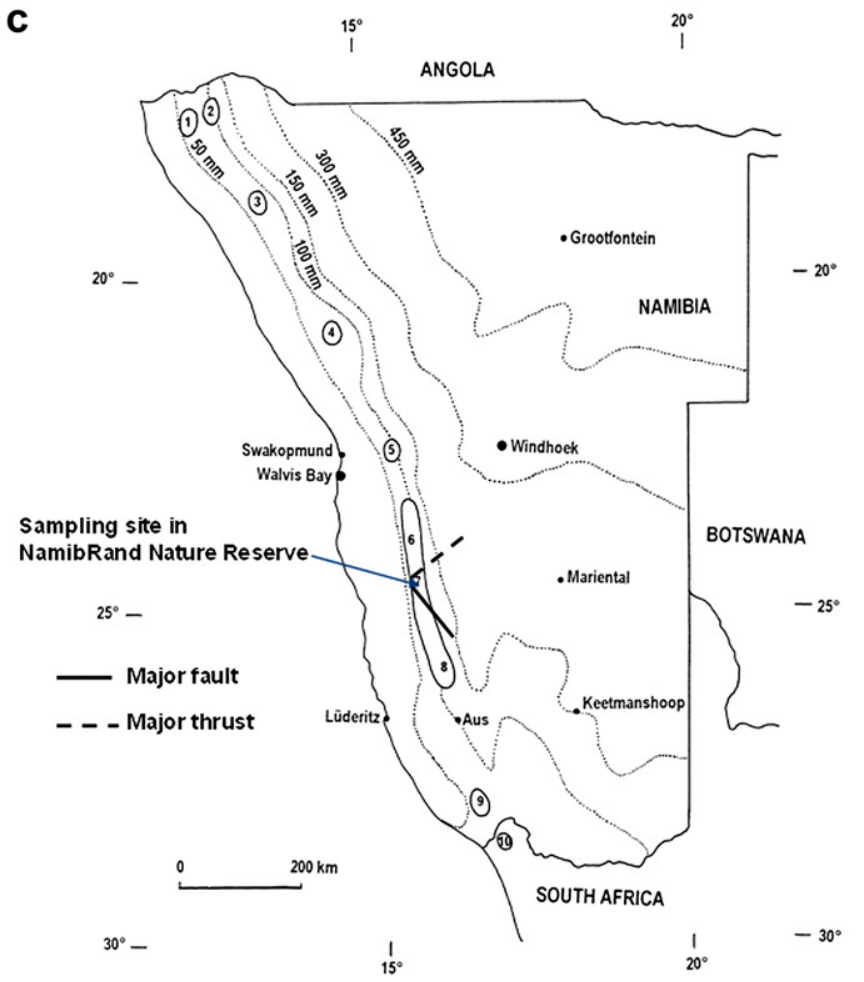

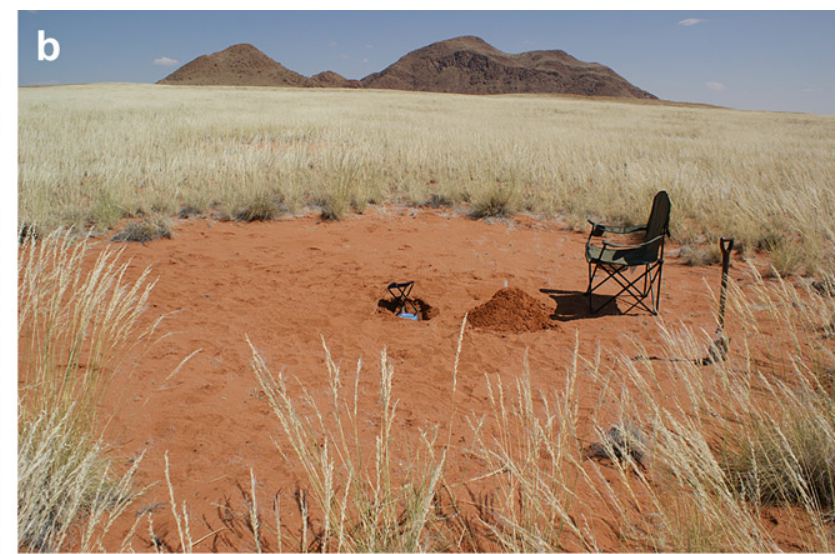

$20^{\circ}$

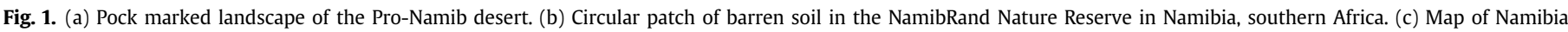

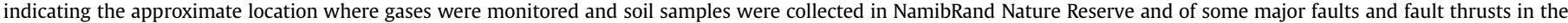
vicinity of the sampling site.

close, Albrecht et al. (2001) proposed that termites were involved in both phenomena and that the fairy circles were caused by a substance associated with termite nests. In order to explain the circular shape of the patches, Albrecht et al. (2001) proposed that the biologically active factor central to their hypothesis may be a semi-volatile chemical substance. However, if the factor could diffuse readily to form a circular patch in which inhibition of plant growth occurs, there would need to be an active process whereby the agent is constantly replenished (Albrecht et al., 2001). Jankowitz et al. (2008) concluded that the results of their in situ investigation could be interpreted as supporting Albrecht et al.'s (2001) argument that a "semi-volatile gas" produced in the circle inhibits grass growth.

Surface macroseeps (visible hydrocarbon seepage such as oil) and microseeps (invisible, usually detectable by sensitive instrumentation or the visible result of their effect on the near-surface environment) occur because diffusion, effusion and buoyancy (micro-gas bubbles) allow hydrocarbons to escape from sources and migrate to the surface (Jones et al., 2000; Mello et al., 1996; Van der Meer et al., 2000; Yang et al., 2000). The surface expression of a geochemical microseep can take many forms including geobotanical anomalies, anomalous hydrocarbon concentrations in soil, water and atmosphere, microbiological anomalies, anomalous nonhydrocarbon gases, mineralogical changes such as the formation of calcite and certain magnetic iron oxides, and altered magnetic properties of soils (Jones et al., 2000; Schumacher and LeSchack, 2002; Yang et al., 2000). Most geochemical signatures display as apical or halo-like (Schumacher and LeSchack, 2002). An apical anomaly, e.g. hydrocarbons, is greatest above the source and a halo anomaly occurs towards the edge of the source, outside of the anomaly, or forms a circular pattern around an apical anomaly. A general model of hydrocarbon-induced geochemical and geophysical alteration of soils illustrates anomalous surface concentrations (apical or halo formation), carbonate precipitation, bacterial degradation of hydrocarbons, high resistivity anomaly at 
the surface, magnetic anomaly and oxidising and reducing zones (Schumacher, 1996).

Microseepage rates and surface hydrocarbon concentrations can vary drastically over time. Surface hydrocarbon seeps and soil geochemical anomalies have been shown to appear and disappear in relatively short times, weeks, months or years (Schumacher and LeSchack, 2002). The flux responds to changes in barometric pressure as well as daily, monthly and yearly cycles. A background seep (noise) can occur around the seepage-induced alteration and hyperspectral remote sensing is generally used to detect trends of circular patterns (halo formation) around a central vent or straight lines (faults) when searching for surface indicators of seeps (Smith et al., 2004; Van der Meer et al., 2000). Near-surface geochemical anomalies are closely associated with faults and fractures (Jones et al., 2000; Van der Meer et al., 2000). Anomalies seemingly not coincident with known faults, fractures or other obvious pathways may present processes not completely understood or recognised (Jones et al., 2000). Although hydrocarbon seepage is more common than is generally believed, it is relatively rare for seeps to overlie major oil or gas fields (Macgregor, 1993). Therefore, the perceived seep anomaly does not necessarily imply the presence of economic recoverable hydrocarbons at depth (Yang et al., 2000). The potential for finding large hydrocarbon accumulations in the Nama Basin is limited as large reservoirs would not be filled due to breaching of possible accumulations (Summons et al., 2008).

Hydrocarbon microseepage is reported to create a chemically reducing zone in the soil column at depths shallower than would be expected in the absence of seepage (Van der Meer et al., 2002). The seep stimulates bacterial activity which further decreases soil oxygen concentration, which, in turn, changes soil chemistry and influences the availability of trace elements to plants (Van der Meer et al., 2002). This environmental change affects the root structure of the vegetation and causes visible stress in plants such as reduced growth, chlorosis of the leaves and plant mortality.

The objectives of this pilot study were to explore, for the first time, a possible geochemical origin of the fairy circles and investigate the hypothesis that fairy circles are the surface expression of geochemical hydrocarbon microseepage.

\section{Materials and methods}

\subsection{Study area}

Van Rooyen et al. (2004) collected soil samples from sites, covering a comprehensive region from the Kaokoveld in the north, down to Kubus in the north of South Africa, including the vicinity sampled in this present study. Bioassays conducted on the soils from the different localities revealed the same pattern (Van Rooyen et al., 2004). It is therefore assumed that the causal factor responsible for the fairy circle phenomenon is the same for all circles and hence a single site, based on its relative ease of accessibility, was selected for the current study. Gas measurements were performed from 4 to 6 April 2009 in the NamibRand Nature Reserve in

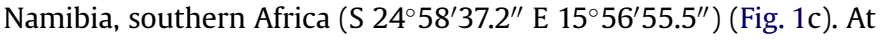
this site five fairy circles were selected within a radius of $50 \mathrm{~m}$. Three of the circles (circles 1, 2 and 3) were typical barren patches (Fig. 1b), whereas circle 4 was a patch with dead grass tufts and circle 5 contained a mixture of both dead grass tufts as well as live tufts showing severe signs of chlorosis. Gas measurements were also taken in the matrix equidistant between the circles.

Near-surface soil was collected at a depth of approximately $50 \mathrm{~cm}$ in the centres of circle 4 and circle 5 . Soil was also collected in the centres of circle 1.3 and circle 2.1, and in the matrix (matrix 1.3 and 2.1), in the NamibRand Nature Reserve in 2007 (S $24^{\circ} 58^{\prime} 44.9^{\prime \prime}$; E $15^{\circ} 57^{\prime} 05.9^{\prime \prime}$ ). Soil samples 1.3 (circle and matrix) were collected at approximately $1 \mathrm{~m}$ below the surface and soil samples 2.1 (circle and matrix) were collected at the surface.

\subsection{Measurement of $\mathrm{CO}$ and $\mathrm{O}_{2}$}

Gas measurements were recorded between 15:00 and 16:00 on day 1, between $17: 00$ and 18:00 on day 2 , and between $11: 40$ and $12: 05$ and $16: 30$ and $16: 50$ on day 3 in circles $1-3$. Gas measurements of the relatively newly formed circles (circles 4 and 5) occurred between $12: 12$ and $12: 30,15: 50$ and $16: 15$, and $17: 50$ and $18: 50$ on day 3 .

A GreenLine 8000 Portable gas analyser (Elemental Analytics (Pty) Ltd, Boksburg, Johannesburg, South Africa) equipped with a gas sampling probe, electrochemical (EC) sensors for $\mathrm{CO}, \mathrm{H}_{2} \mathrm{~S}, \mathrm{NO}_{2}$ and $\mathrm{O}_{2}$ and non-dispersive infra-red (NDIR) sensors for $\mathrm{CO}$ and $\mathrm{CO}_{2}$ were used for sampling in the field. Detector response time to $90 \%$ of readings for the electrochemical sensors (EC) was $40 \mathrm{~s}$ for CO and $20 \mathrm{~s}$ for $\mathrm{O}_{2}$. The $\mathrm{CO}$ non-dispersive infrared (NDIR) adsorption response time was $50 \mathrm{~s}$ to $90 \%$ of reading. Regrettably, the gas analyser was not equipped with sensors for methane and combustible gases $\left(\mathrm{C}_{x} \mathrm{H}_{y}\right)$ and thus $\mathrm{CO}$ was selected as a marker for the presence of natural gas.

Two litre funnels were buried upside down in the soil at a depth of $20-30 \mathrm{~cm}$ so that only part of the funnel stem was visible above the soil. The stem of the funnel was covered loosely by a centrifuge tube to allow an unrestricted flow of gases. Initial measurement of gases (Day 1) commenced after a waiting a period of $2 \mathrm{~h}$ after the funnels were buried. For days 2 and 3 the funnels were left in place overnight. The presence of gases was monitored by inserting the gas sampling probe of the gas analyser into the buried funnels in the centre of the circles, as well as equidistant between the circles (controls) in the matrix.

\subsection{Extraction of compounds from soil}

Stir bar sorptive extraction (SBSE) with Twisters $^{\mathrm{TM}}$ (Gerstel $^{\mathrm{TM}}$, Chemetrix, Midrand, South Africa) was initially used for the solventless extraction of hydrocarbon analytes from the soil. However, when the Twister ${ }^{\mathrm{TM}}$ was removed from the soil it was discovered that a black seemingly tar-like substance covered the ends of the Twister ${ }^{\mathrm{TM}}$. Because the Twister ${ }^{\mathrm{TM}}$ is a magnetic stir bar coated with a volume of polydimethyl siloxane (PDMS) the substance had to possess magnetic properties for it to cling to the poles of the stir bar. Inspection of the substance with a magnifying glass clearly showed a glut of magnetic particles. The particles clinging to the Twisters $^{\mathrm{TM}}$ were problematic during sample desorption. An alternative solventless extraction method was therefore developed to specifically avoid magnetising soil minerals.

A $10.5 \mathrm{~cm}(0.02 \mathrm{~g})$ length of a silicone elastomer medical grade tubing $(0.64 \mathrm{~mm} \mathrm{OD} \times 0.3 \mathrm{~mm}$ ID, Sil-Tec, Technical Products, Georgia, USA) with a sorption volume of $26 \mu \mathrm{l}$ was used for solventless extraction of the soil samples (Fig. 2). To prevent sand from entering the PDMS tube and to facilitate ease of handling the length of PDMS tubing was joined at the ends with a $1 \mathrm{~cm}$ piece of capillary column $(250 \mu \mathrm{m}$ ID) to form a loop. A $40 \mathrm{ml}$ glass vial, fitted with a solid screw cap coated on the inside with polytetrafluoroethylene (PTFE), was filled with $40 \mathrm{~g}$ soil. A PDMS loop was submerged in the soil. The vial was placed in an oven at $50^{\circ} \mathrm{C}$ for $60 \mathrm{~min}$. After extraction of the soil the PDMS loop was inserted into a $17.8 \mathrm{~cm}$ long glass desorption tube ( $4 \mathrm{~mm} \mathrm{ID,} 6.00 \mathrm{~mm}$ OD) from Gerstel $^{\mathrm{TM}}$ (Chemetrix, Midrand, South Africa) for thermal desorption into a gas chromatograph-mass spectrometer (GC-MS).

\subsection{Identification of compounds by GC-MS}

The hydrocarbon analytes were thermally desorbed from the PDMS loop using a thermal desorber system (TDS) from Gerstel ${ }^{\mathrm{TM}}$ installed on a Hewlett Packard (HP) GC 1530A coupled to a HP 5973 


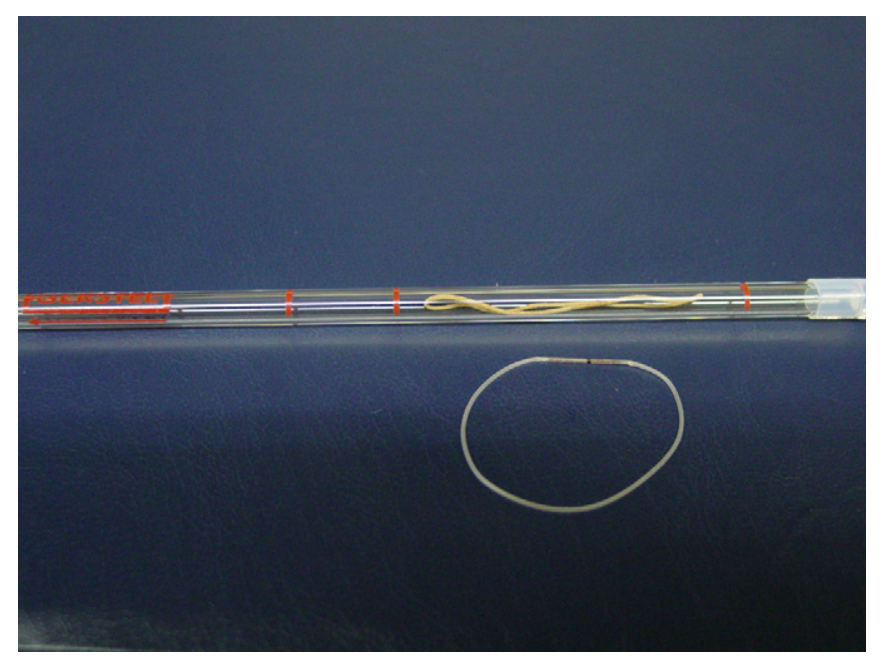

Fig. 2. PDMS loop (tube ends joined with a piece of capillary column) used for the extraction of soil (bottom), PDMS loop after extraction and inserted inside a TDS tube for desorption into a GC-MS (top). See Section 2.3 for details.

mass selective detector (MSD) (Chemetrix, Midrand, South Africa). Splitless desorption was from $30^{\circ} \mathrm{C}(2 \mathrm{~min})$ at $30^{\circ} \mathrm{C} / \mathrm{min}$ to $250{ }^{\circ} \mathrm{C}$ (10 $\mathrm{min}$ ). The desorption flow rate was $50 \mathrm{ml} / \mathrm{min}$ (Helium, Ultra High Purity, Afrox, Johannesburg, South Africa) at $65 \mathrm{kPa}$. The TDS transfer line temperature was $350^{\circ} \mathrm{C}$. The analytes were cryogenically focused, using liquid nitrogen, at $-10^{\circ} \mathrm{C}$ on a cooled injection system (CIS). The CIS liner contained silicone rubber to improve retention of the volatile analytes during desorption. After desorption, a splitless injection (purge on at $30 \mathrm{~min}$, purge flow $60 \mathrm{ml} /$ min, solvent vent mode) was performed by heating the CIS from $-10^{\circ} \mathrm{C}$ at $6{ }^{\circ} \mathrm{C} / \mathrm{s}$ to $250^{\circ} \mathrm{C}$ for $10 \mathrm{~min}$. The GC oven temperature programme was $-10^{\circ} \mathrm{C}(2 \mathrm{~min})$ at $10^{\circ} \mathrm{C} / \mathrm{min}$ to $300{ }^{\circ} \mathrm{C}(10 \mathrm{~min})$. The GC column was a Zebron, ZB1 $30 \mathrm{~m} \times 250 \mu \mathrm{m}$ ID $\times 0.25 \mu \mathrm{m}$ film thickness (Phenomenex, Separations, Randburg, South Africa), the velocity of the carrier gas (helium) was $42 \mathrm{~cm} / \mathrm{s}(1.3 \mathrm{ml} / \mathrm{min}$ ) and the column head pressure was $65 \mathrm{kPa}$ in the constant pressure mode. The GC-MS transfer line was at $280^{\circ} \mathrm{C}$, the mass scan range was 35-350 atomic mass units (amu) in full scan mode, the source $\left(\mathrm{EI}+\right.$ ) temperature $230^{\circ} \mathrm{C}$, the MS quadrupole temperature $150^{\circ} \mathrm{C}$, the ionisation energy $70 \mathrm{eV}$ and the electron multiplier voltage (EM) $1700 \mathrm{~V}$. Compounds were identified by mass spectral comparison of the samples to that of the mass spectra found in a commercial library (Wiley). Matches of the mass spectra of the components to that of the library were $\geq 80 \%$.

\section{Results and discussion}

\subsection{Gas detection}

\subsubsection{Plant stress response to natural gas seeps}

Several studies have reported a relationship between microseepage from subsurface sources and the stress response of plants to long-term anaerobic conditions and its use in gas/hydrocarbon exploration (Jones et al., 2000; Mello et al., 1996; Noomen et al., 2003; Smith et al., 2004; Van der Meer et al., 2000; Xu et al., 2008). Hydrocarbon seepage influences the soil and the vegetation around the seep. The seepage alters the soil atmosphere and the mineralogy. The gases that seep to the surface partially displace the soil atmosphere, including soil oxygen and consequently the soil atmosphere is depleted of oxygen. An oxygen poor environment surrounding roots can severely damage plant growth in the seep migration pathway, causing visible plant stress (Smith et al., 2004). Although natural gas is considered not toxic to plants, visible symptoms due to natural gas seepage are reduced plant growth, chlorosis of the leaves and plant mortality. Noomen et al. (2003) reported a circle of bare soil occurring at the centre of a gas leak, and on the edge of the necrotic circle a ring of healthy vegetation flourished. Van Rooyen et al. (2004) reported lower biomass in the fairy circles and the highest biomass at the edge (ringing vegetation) of the patches.

Smith et al. (2004) experimented with the effect of natural gas on germinating seeds and on a fully established grass crop. Injection of natural gas into soil beneath an established grass crop caused a circle of chlorosis: a region of lighter green grass which became more yellow as the experiment progressed, and a reduction of growth of the grass around the area of gas injection. For seedlings, most plants germinated but did not grow in the gas seep.

Certain plant species appear to be less sensitive to anaerobic soil conditions than others (Yang et al., 2000). An anomalous distribution of maple trees occurs in an area of maximum methane seepage and minimum soil oxygen conditions where typically oak-hickory vegetation is expected to occur (Lost River gas field, Appalachian Mountains, West Virginia, United States of America) (Yang et al., 2000). This vegetation anomaly seems to relate to anaerobic soil conditions that influence the mycorrhizal fungi living on the root hairs of the trees. Fungi on maple trees appear to tolerate the anaerobic soil conditions better than the mycorrhizal fungi living on the roots of oak trees (Yang et al., 2000). Joubert (2008) reported the absence of vesicular arbuscular mycorrhizae (VAM) in the roots of plants collected from within the fairy circles. In contrast, VAM occurred in most of the roots of plants collected between the circles and on the edge of circles (Joubert, 2008). Mycorrhiza are aerobic organisms (Torti et al., 1997) and soil that becomes anaerobic for considerable periods of time generally loses its mycorrhizal component (Ingham, 2010). The absence of mycorrhizal fungi in the roots of plants from within circles suggests anaerobic soil conditions within the circles. Soil conditions favouring anaerobic bacteria in the circles were indeed implicated by Eicker et al. (1982) who reported a greater density of anaerobic bacteria and a lower density of aerobic bacteria within barren circles compared with the matrix.

Hydrocarbon microseepage creates a chemically reducing zone in the soil at depths shallower than would be expected in the absence of seepage (Van der Meer et al., 2002). Such leakage stimulates the activity of hydrocarbon-oxidising bacteria, which further decreases soil oxygen concentration while increasing $\mathrm{CO}_{2}$ and organic acids (Van der Meer et al., 2002). These changes can affect the $\mathrm{pH}$ and the redox potential $\left(E_{\mathrm{h}}\right)$ in soils which in turn affect the solubility of trace elements and consequently their availability to plants (Schumacher, 1996; Van der Meer et al., 2002). Changes in the soil chemistry environment can therefore affect plant vigour, resulting in vegetation anomalies (Van der Meer et al., 2002). Joubert (2008) and Van Rooyen et al. (2004) demonstrated that plants failed to flourish when grown in soil collected from within fairy circles, compared to the vitality of plants grown in soil collected from the edge of the circle (stimulated growth) and the matrix (intermediate growth). An anaerobic soil environment in the seep chimney can alter the soil chemistry which leads to the dissolution or precipitation of minerals and the mobilisation or immobilisation of certain elements in the seep chimney (Van der Meer et al., 2002). Results of Joubert's study suggest that the altered soil, when removed from the circle, retained its altered state causing an adverse effect on plant vitality. Seepage-induced geobotanical anomalies appear to be primarily related to anaerobic soil conditions.

\subsubsection{Bare soil circles}

Fig. 3 illustrates the simultaneous recording of oxygen $\left(\mathrm{O}_{2}\right)$ and carbon monoxide (CO) inside circles and at control sites. Levels of $\mathrm{O}_{2}$ and $\mathrm{CO}$ were $20.9 \%$ (EC) and $0.000 \%$ (NDIR), respectively, prior to 
insertion of the probe into the funnel $(-1 \mathrm{~s})$. A drop in $\mathrm{O}_{2}$ from $20.9 \%$ to $20.8 \%$ followed by an emission of CO of $0.001 \%$ was detected inside of the barren soil circles 1 and 2 on day 1 . Although $\mathrm{CO}$ was not measured a drop in $\mathrm{O}_{2}$ from $20.9 \%$ to $20.8 \%$ was observed in barren soil circle 3 . On day 2, $\mathrm{CO}$ emissions of 1 part per million (ppm) (EC) was detected after a drop in $\mathrm{O}_{2}$ of $0.1 \%$ was observed inside barren soil circles 1 and 2 and a $0.2 \%$ drop in $\mathrm{O}_{2}$ was observed inside barren soil circle 3 although $\mathrm{CO}$ was not detected. The level of $\mathrm{O}_{2}$ was constant at $20.9 \%$ and $\mathrm{CO}$ was not detected for a control site $(n=2)$ in between the barren soil circles. During the mid day session on day 3 a $0.2 \%$ drop in $\mathrm{O}_{2}$ was observed followed by a $\mathrm{CO}$ emission of up to $0.005 \%$ for circle 1 . A $0.2 \%$ drop in $\mathrm{O}_{2}$ was observed although CO was not detected inside circle 2. A $0.2 \%$ drop in $\mathrm{O}_{2}$ was measured, followed by a $\mathrm{CO}$ emission of up to $0.007 \%$ inside of circle 3 . The $\mathrm{O}_{2}$ was constant at $20.9 \%$ and no $\mathrm{CO}$ was observed for the control site monitored at 12:05. During the late afternoon session a $0.1-0.2 \%$ drop in $\mathrm{O}_{2}$ but no $\mathrm{CO}$ was detected inside of circles 1,2 and 3.

A drop in $\mathrm{O}_{2}$ levels was not observed during three previous measurements in the matrix, the only exception was on day 3 when the site was monitored at 16:45, a $0.2 \%$ drop in $\mathrm{O}_{2}$ was observed, but CO was not detected (Fig. 3 ).

Concentrations of $\mathrm{CO}$, when greater than zero, were always measured after first observing a drop in $\mathrm{O}_{2}$ (Fig. 3).

\subsubsection{Newly formed circles}

The two new circles, one being a perfectly circular patch of dead vegetation and another patch consisting of a mixture of both dead vegetation and mature, alive, yellowed plants, were pointed out to us at the end of day 2 and thus the two new circles were monitored on day 3 only. The two patches were bordering each other. A $0.2 \%$ drop in $\mathrm{O}_{2}$ followed by $\mathrm{CO}$ of up to $0.028 \%$ was observed at $12: 12-12: 30$, a $0.2 \%$ drop in $\mathrm{O}_{2}$ followed by $\mathrm{CO}$ of $0.001 \%$ was detected at $15: 50$, while a $0.3 \%$ drop in $\mathrm{O}_{2}$ and $0 \mathrm{ppm} \mathrm{CO}$ were measured at 17:55, whereas at 18:50 the $\mathrm{O}_{2}$ remained constant at $20.9 \%$ and $\mathrm{CO}$ was not detected inside the circle of dead vegetation (Fig. 4). The patch consisting of a mixture of both dead and stressed vegetation was monitored and a $0.1 \%$ drop in $\mathrm{O}_{2}$ followed by $\mathrm{CO}$ of up to $0.032 \%$ was observed at $16: 03-16: 15$, while a $0.1 \%$ drop in $\mathrm{O}_{2}$ and $0 \mathrm{ppm}$ CO were detected at 17:50. The control site (15:57) for

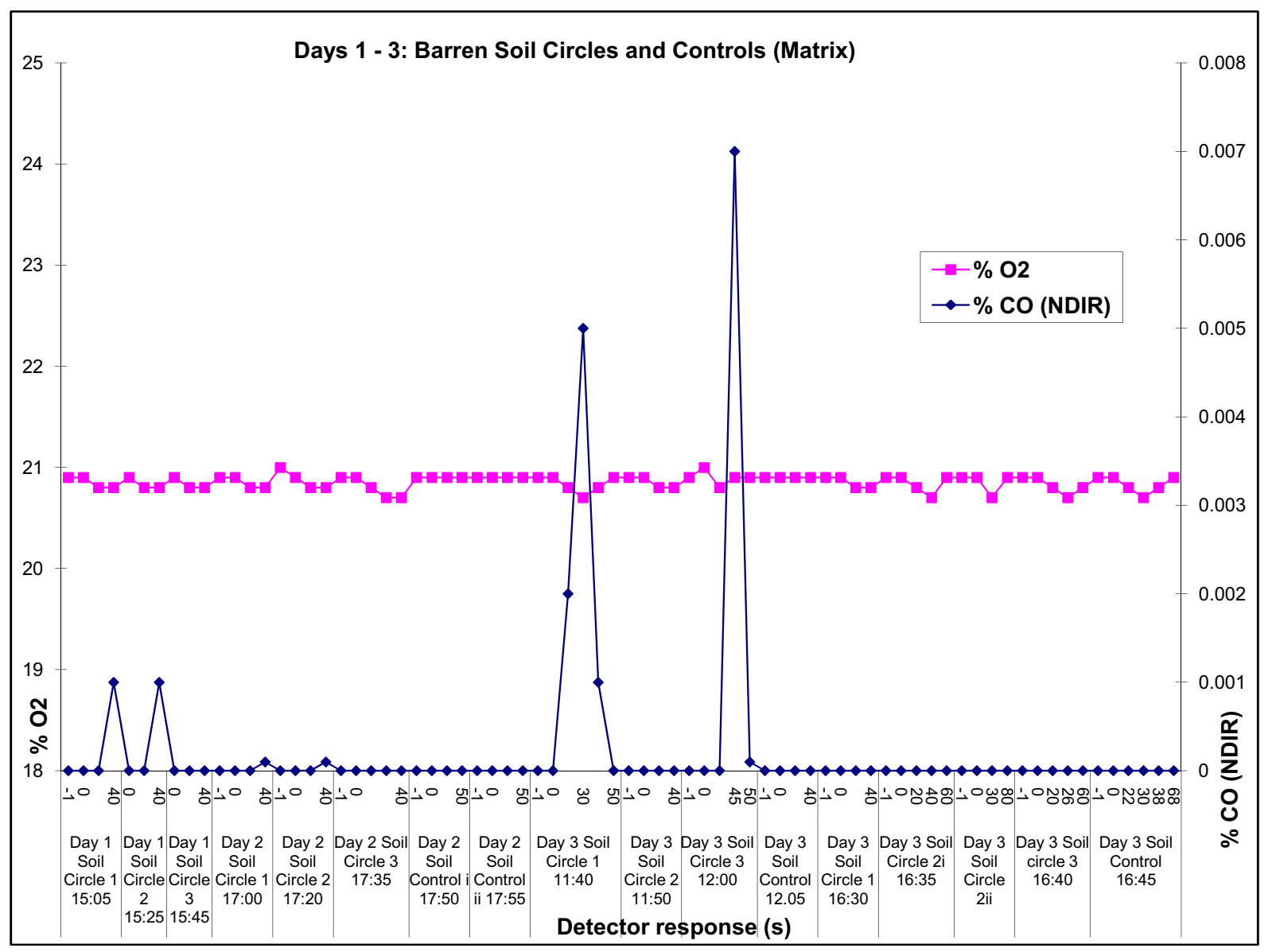

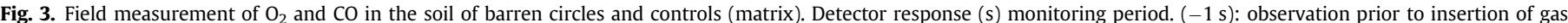

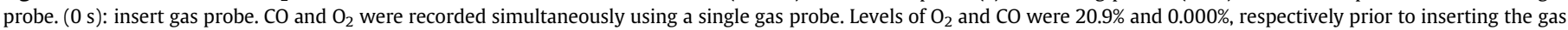

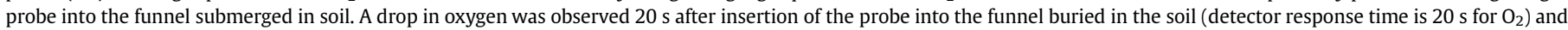

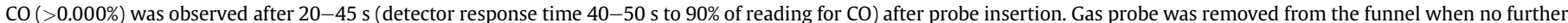

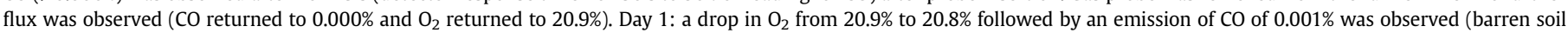

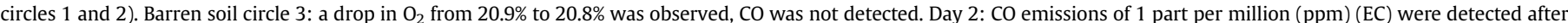

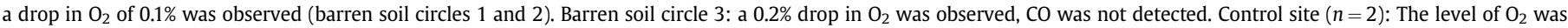

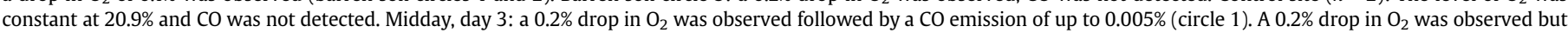

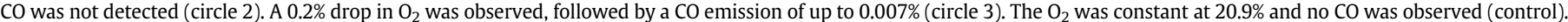

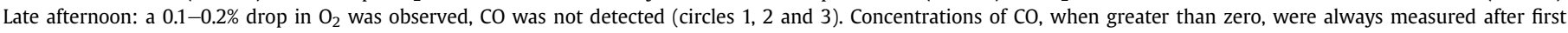
observing a drop in $\mathrm{O}_{2}$. 
the newly formed circles measured a constant $20.9 \% \mathrm{O}_{2}$ and $\mathrm{CO}$ was not detected.

The results show that $\mathrm{CO}$ emissions are of an episodical nature and not continuous. The highest $\mathrm{CO}$ emissions were measured at 12:00 and 16:00. Gas flux is dependent on atmospheric pressure changes. Gas flux is at its highest when barometric pressure is at its lowest. The $0.1-0.3 \%$ drop in $\mathrm{O}_{2}$ does not fully account for the levels of $\mathrm{CO}$ detected at $0.000-0.032 \%$. This discrepancy between the displacement of $\mathrm{O}_{2}$ and the emission of $\mathrm{CO}$ indicates the presence of gases other than $\mathrm{CO}$. Contrary to our expectation, the gas analyser was not equipped with sensors for methane and combustible gases $\left(\mathrm{C}_{x} \mathrm{H}_{y}\right)$. However, $\mathrm{CO}$ attributed to natural sources is not only an indicator of natural gas but it may also result from the oxidation of hydrocarbons, notably methane. Therefore, the measurement of $\mathrm{CO}$ in the circles points to the presence of natural gas. Determining the composition of the gases within the seeps will need further investigation. Also, we anticipate that during peak gas seepage the depletion of $\mathrm{O}_{2}$ in the subsurface soil (as opposed to the somewhat small drop observed in our rather unsophisticated set-up of inverted funnels with loosely covered stems) will be dramatically more than $0.3 \%$. No $\mathrm{NO}_{2}$ or changes in $\mathrm{CO}_{2}$ were detected and levels may be indistinguishable from ambient values. Abnormal $\mathrm{CO}_{2}$ concentrations in soils are non-specific for petroleum and can result from processes other than microbial oxidation of hydrocarbons (Schumacher, 1996).

\subsection{TDS-CIS-GC-MS of extracted soil samples}

Typically the method for isolating and analysing hydrocarbons from seep-soils is Soxhlet extraction of, often, a sizeable soil sample with large volumes of hazardous (chlorinated) solvents which have the potential for artefact (e.g. hydrocarbons) introduction, followed by the analyses of microlitre amounts of the diluted final extract (Rangel et al., 2003; Summons et al., 2008). In contrast, we developed a simple, cheap, nonhazardous solventless extraction technique for the introduction of the total amount of sorbed analytes into a GC-MS. Because the method is solventless the potential for artefact introduction is minimised and smaller sized soil samples can be extracted.

\subsubsection{Saturated alkanes}

Soil samples containing active (fresh) migrated hydrocarbons produce a gas chromatogram of undegraded $n$-alkanes, branched alkanes, biomarker signatures and a minor naphthenic hump (unresolved complex mixture of hydrocarbon compounds) (Abrams, 2005; Rangel et al., 2003). Soil samples containing passive (dormant stage) migrated hydrocarbons produce a gas chromatogram showing severe degradation characterised by only an elevated unresolved complex mixture (UCM) (Abrams, 2005). Hydrocarbon-degrading bacterial populations preferentially utilise $n$-alkanes relative to branched alkanes (Hamamura et al., 2005). The signature of soils from dormant

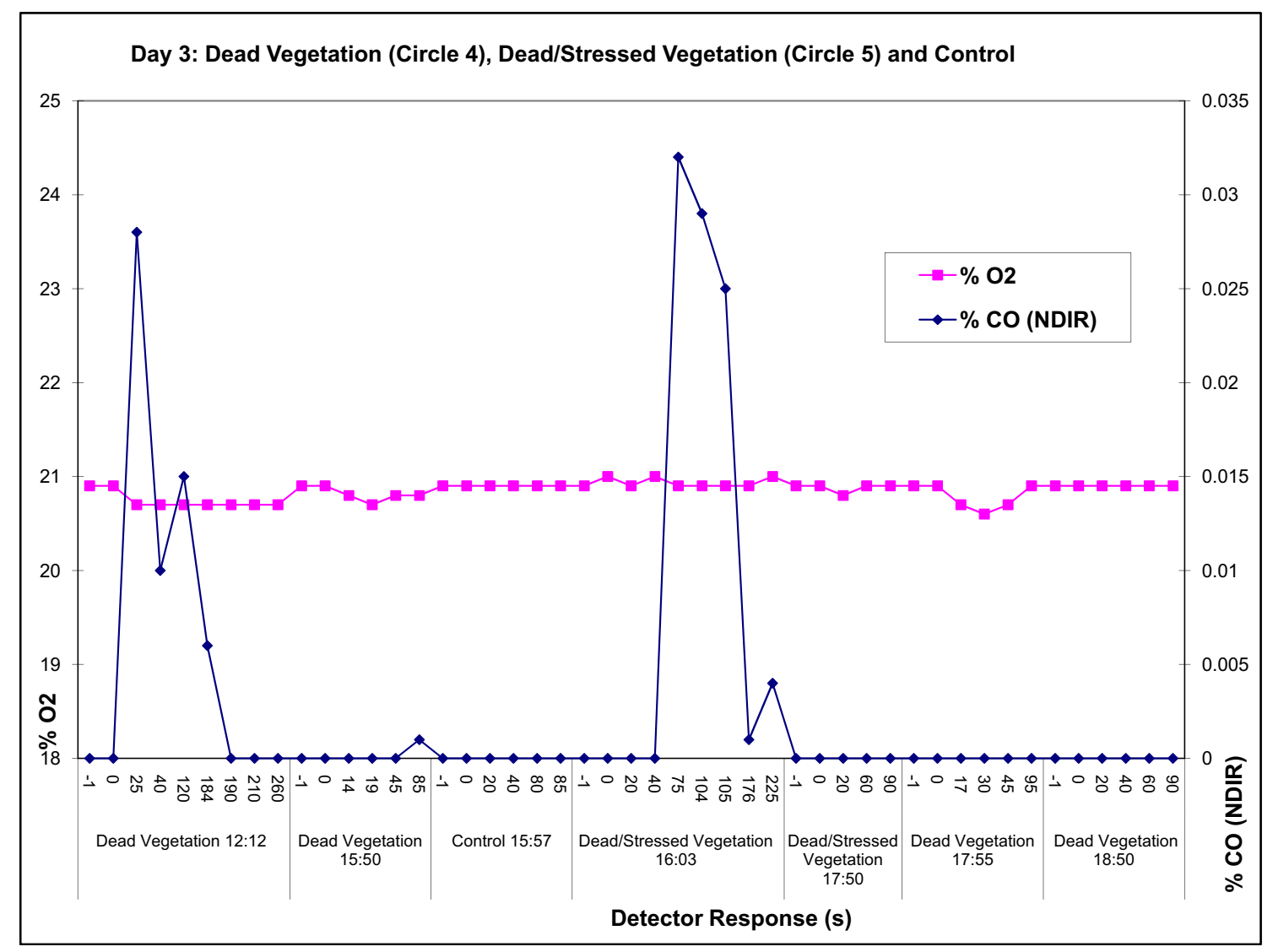

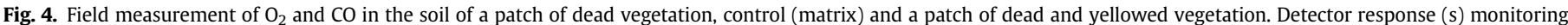

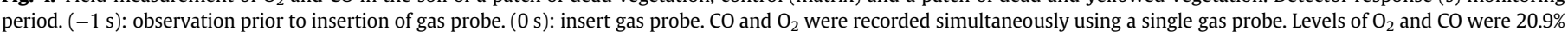

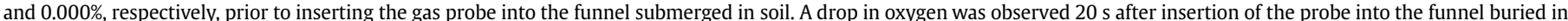

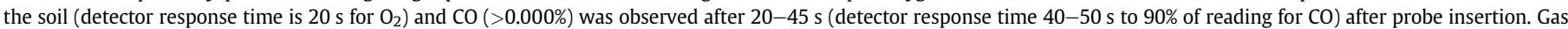

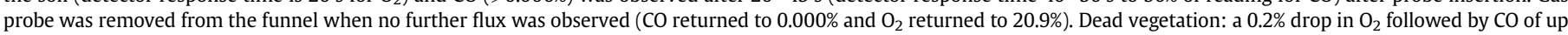

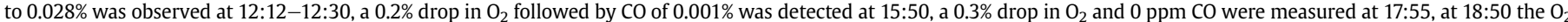

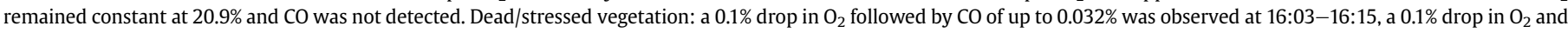
0 ppm CO were measured at 17:50. Control site (15:57): $\mathrm{O}_{2}$ was constant at $20.9 \%$ and CO was not detected. 
stage migrated hydrocarbons, recharged with a recent seepage, is similar to the passive seep but with the addition of resolvable compounds $C_{12}-C_{20}$ (Abrams, 2005). An unresolvable hump $<C_{23}$ is representative of a migrated thermogenic portion (Abrams, 2005).

Chromatograms of soils from the newly formed patches display some resolved peaks on an elevated unresolved hump (Fig. 5). Poorly resolved $n$-alkanes in the $C_{13}-C_{18}$ range are present while the resolvable compounds consist of almost entirely branched saturated alkanes $\left(\mathrm{C}_{12}-\mathrm{C}_{20}\right)$. These features are consistent with a dormant stage seep recharged with seepage at some stage. This chemical signature of an elevated unresolved hump (dormant stage degraded seep) with the addition of resolvable saturated alkanes (active seep) is substantiated by the visual appearance of notably the patch containing both dead (past seep activity characterised by an UCM) and yellowed vegetation (a dormant stage permits new plant growth, while chlorosis is the consequence of relatively recent seepage resulting in the addition of resolvable compounds in the $\mathrm{C}_{12}-\mathrm{C}_{20}$ range) (Fig 5 ).

The ratio of the acyclic $C_{19}$ and $C_{20}$ isoprenoid hydrocarbons, pristane $(\mathrm{Pr})$ and phytane $(\mathrm{Ph})$, generally reflects the nature of the organic matter (maturity of the seep source) and the redox potential in the depositional environment during early diagenesis of chlorophyll (phytol chain), the main precursor of pristane and phytane (Osuji and Antia, 2005). Ph was detected in the soil of the two newly formed circles, while the presence of Pr could not be confirmed. However, Pr is degraded preferentially to Ph (Osuji and Antia, 2005). Both seeps are degraded as are evidenced by their chromatograms showing elevated unresolved humps (Fig. 5).

\subsubsection{Alkenes}

Bacteria are ubiquitous in the environment but will concentrate where a food source, such as a hydrocarbon seep, is available (Schumacher and LeSchack, 2002). Microorganisms feeding on

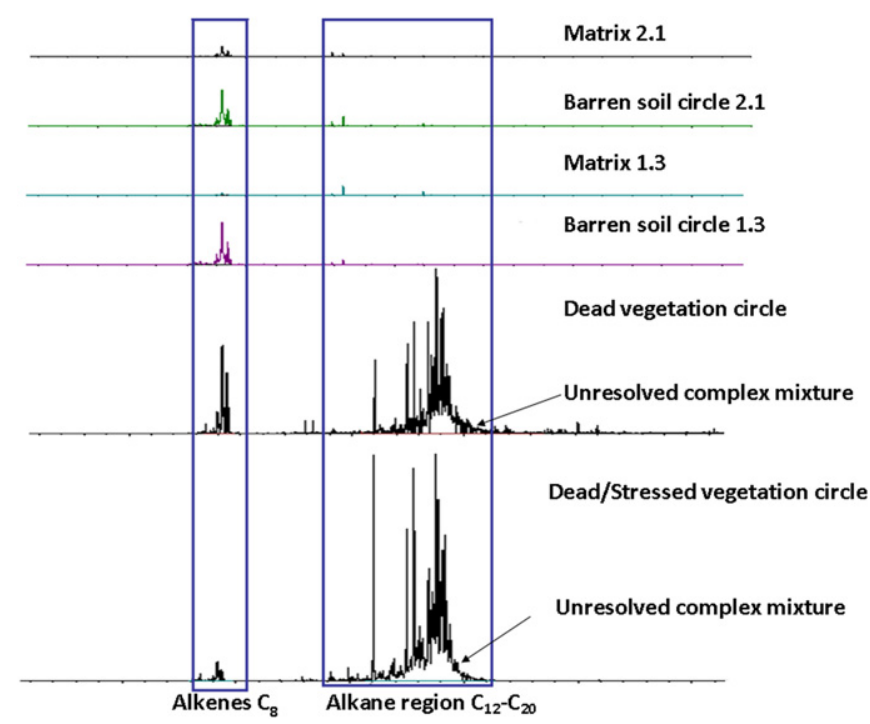

Fig. 5. Reconstructed ion chromatogram (112 amu) of alkenes (microbiological degradation product of alkanes) relative to alkanes measured in soils collected from barren soil circles (circles 2.1 and 1.3), between barren soil circles (matrix 2.1,1.3) and two newly formed circles (dead and stressed vegetation; dead vegetation). Samples 2.1: soil collected at surface. Samples 1.3: soil collected approximately $1 \mathrm{~m}$ below surface. Newly formed circles: soil collected approximately $50 \mathrm{~cm}$ below surface. Barren soil circles and the two newly formed circles have relatively more alkenes present compared to the alkenes present in the matrix. Bare soil circles and matrix: UCM absent. Two newly formed circles: UCM (degraded seepage) present with addition of resolvable alkanes (active seepage). hydrocarbons will degrade the hydrocarbons. Also, microbial degradation of alkanes to alkenes can occur under anaerobic conditions (Grossi et al., 2008; Jones et al., 2000; Morikawa et al., 1996).

Fig. 5 shows the reconstructed ion chromatograms (112 amu) of acyclic alkenes ( $n$-octene, branched olefins $\left(\mathrm{C}_{8} \mathrm{H}_{16}\right)$ ) present in the soil samples. The soil collected from inside (centre) the barren soil circles (circle 1.3, circle 2.1 ) has relatively more alkenes (total peak areas of 104 and 86 (arbitrary units indicated in the alkene window)) present when compared to the alkenes (total peak areas of 5 and 22) present in the matrix (matrix 1.3, matrix 2.1). For the newly formed circles the soil from the patch of dead vegetation contained alkenes with a total peak area of 52 and the patch with both dead and yellowed vegetation contained alkenes with a total peak area of 26 (Fig. 5).

The higher levels of alkenes detected in soil collected inside (centre) the barren circles compared to the lower levels of alkenes present in soil collected between the barren circles (matrix) point to the availability of a more abundant food source for microbial consumption inside the circle relative to outside the circle (matrix). Eicker et al. (1982) recorded the highest activity of anaerobic bacteria in the barren patch and the lowest at the edge. In contrast, Eicker et al. (1982) reported that the lowest aerobic microbial density occurred in the patch and the highest on the edge inferring the presence of a diminished $\mathrm{O}_{2}$ zone in the seep. These distinct microbial patterns support the geochemical signature of a reducing microseep area above the hydrocarbon source with an outside edge of an oxidised area. Bacterial activity inside a hydrocarbon microseep can cause changes leaving the near-surface materials more dense and resistant to erosion (Xu et al., 2008). Moll (1994) found that the fairy circle soils were slightly more compact than those in the matrix.

Van Rooyen et al. (2004) noted that soil resistance was highest in the barren patch soil and lowest in the edge soil (ringing vegetation). The hydrocarbon microseepage model shows a higher resistivity anomaly at the surface (Schumacher and LeSchack, 2002). Potassium (K) precipitates in a halo anomaly in high $\mathrm{pH}$ soils over a seep (Monson and Shurr, 2003). The $\mathrm{pH}$ of the soil is raised due to bacterial activity resulting in the addition of bicarbonate to pore water (Schumacher, 1996). Van Rooyen et al. (2004) reported alkaline soil pH values of mostly 8-9, higher levels of $\mathrm{K}$ $(\mathrm{mg} / \mathrm{kg})$ at the edge (ringing vegetation) of barren patches and lower levels of $\mathrm{K}(\mathrm{mg} / \mathrm{kg})$ within barren patches. Mineral alteration related to hydrocarbon microseepage can result in low $\mathrm{K}$ anomalies in soils (Van der Meer et al., 2002).

Active hydrocarbon migration may be identified by ratios of alkanes to alkenes (Harbert et al., 2006). High saturate to olefin (unsaturated compound) values $(>1$ ) are anomalous and imply an active seep (Harbert et al., 2006). The alkane/alkene ratios for the two newly formed circles were calculated as total peak area alkanes/ total peak area alkenes of the reconstructed ion chromatograms $112 \mathrm{amu}$ (Fig. 5). The circular patch of dead vegetation has an alkane/alkene ratio of 7 and the circular patch of both dead and yellowed vegetation has an alkane/alkene ratio of 72 . These high values indicate very active seepage, notably so in the case of the circular patch of both dead and yellowed vegetation (chlorosis is indicative of new seep activity). The displacement of $\mathrm{O}_{2}$ and the release of $\mathrm{CO}$ were also the highest for this patch. These two newly formed circular patches are of particular interest. The patch of dead vegetation is evidence of the birth of a vent. The patch of both stressed and dead vegetation is evidence not only of the birth of a vent but also that the seep had a period of activity (dead plants), followed by a dormant period which allowed plants to germinate and reach maturity until the seep became newly active once again, leading to the current state of the patch consisting of mature yellowed vegetation amongst the dead vegetation. 
In contrast to the high alkane/alkene ratios of the two newly formed circles the alkane/alkene ratios for the barren soil circles were 0 . An elevated unresolved hump was absent and saturated alkanes were below detectable levels (Fig. 5). The flux of hydrocarbon seepage is difficult to measure because seeps may be small, episodic and brief (Van der Meer et al., 2002). Seepage and its associated anomalies can disappear and reappear in response to reservoir depletion and repressuring (Schumacher and LeSchack, 2002).

\subsection{Seepage-induced stimulation of vegetation growing on the edge of fairy circles}

Plants on the edge (fringe of ringing vegetation) of fairy circles grow vigorously compared to the intermediate vitality of plants growing in the matrix. It was suggested that plants growing on the edge of a barren patch have more water and nutrients available to them (Van Rooyen et al., 2004). Noomen et al. (2003) reported a seep with a ring of high biomass surrounding a circle of bare soil, the vegetation cover $15 \%$ higher in the ring than in the surrounding area. The authors proposed that the ring of high biomass is most likely due to groundwater collecting at the edge of the halo, since it is known that long-term gas and oil seepage bring groundwater to the surface (Noomen et al., 2003). Albrecht et al. (2001) found a fivefold higher concentration of water in the inner soil of a barren patch, compared to the outer soil of a fairy circle. However, potting trials with fairy circle soils indicated that the stimulatory effect was not merely due to an increased water supply (Van Rooyen et al., 2004). Growth of plants receiving equal amounts of water was still promoted in soil from the edge of the barren patch, thus the soil retained its stimulatory factor (Van Rooyen et al., 2004). Eicker et al. (1982) reported the highest aerobic microbial density at the edge, the lowest aerobic microbial density in the patch and an intermediate microbial density occurred in the matrix, whilst a lower density of anaerobic bacteria occurred at the edge and the highest density of anaerobic bacteria occurred in a barren patch. The presence of a greater anaerobic microbial density occurring in the patch confirms that the patch is a diminished $\mathrm{O}_{2}$ zone. The elevated aerobic microbial population in the edge not only shows that the edge is outside of the diminished $\mathrm{O}_{2}$ zone, but also that the edge retains residual hydrocarbons from the seep, providing for a richer food source to support an aerobic microbial population of higher density when compared to the matrix. The matrix supporting an intermediate microbial density confirms the presence of a less abundant food source compared to the edge (residual seepage) and circle (maximum seepage). The hydrocarbon flux is indeed lower at the edge than in the central vent (Noomen et al., 2003). Van der Meer et al. (2000) reported that hydrocarbon microseepage can act as a fertiliser to the growth of crops. Soil enrichment at the edges of circles is supported by the findings of Van Rooyen et al. (2004) who reported a pronounced stimulation in growth of plants grown in soil collected from the edge of circles in comparison to the plants grown in soil collected from the matrix and inside the circles. The decrease in soil $\mathrm{O}_{2}$ within a seep alters the soil chemistry, creating an unfavourable environment for plant growth. Joubert (2008) and Van Rooyen et al. (2004) reported that plants performed poorly in soil collected from within circles, confirming that the soil within circles retained an antagonistic factor. However, the pronounced stimulation in growth of plants in the edge (ringing vegetation) clearly shows that the edge is outside of the unfavourable soil chemistry zone. The presence of an elevated aerobic microbial population in the edge confirms the availability of a richer food source in the edge when compared to the matrix. Since hydrocarbons can act as a fertiliser to plants, stimulatory plant growth at the edge, outside of the antagonistic soil chemistry zone created by peak seepage (circle), is therefore due to residual hydrocarbons enriching the soil at the edge of the fairy circles. In contrast, plants in the circles are disadvantaged by the unfavourable soil chemistry environment induced by peak hydrocarbon microseepage.

\subsection{Hydrocarbon-induced magnetic anomalies}

The presence of shallow magnetic anomalies over oil and gas fields has been noted for several decades (Eldmore et al., 1987; Liu et al., 2006; Schumacher, 1996; Schumacher and Foote, 2006; Schumacher and LeSchack, 2002; Stone et al., 2004). Approximately $80 \%$ of oil and gas discoveries are associated with hydrocarboninduced magnetic anomalies (Schumacher and Foote, 2006). The near-surface magnetic deposits are generated predominantly from microbial alteration of magnetic minerals and iron-bearing minerals within the hydrocarbon seep. For example, haematite is altered to magnetite under anaerobic conditions in the presence of hydrocarbon microseepage (Eldmore et al., 1987; Liu et al., 2006; Schumacher, 1996; Schumacher and Foote, 2006; Schumacher and LeSchack, 2002; Stone et al., 2004). In addition, hydrogen sulphide $\left(\mathrm{H}_{2} \mathrm{~S}\right)$ is created by bacterial activity. $\mathrm{H}_{2} \mathrm{~S}$ reacts with goethite to produce magnetite and sometimes goethite is altered to magnetic forms of haematite (Van der Meer et al., 2002). Walden et al. (1999) reported both haematite and goethite within Namib dune sediments.

Fig. 6a shows a magnetic stir bar with magnetised soil particles accumulated from $40 \mathrm{~g}$ soil collected in the patch of dead and yellowed vegetation and Fig. $6 \mathrm{~b}$ shows a magnetic stir bar with magnetised soil particles accumulated from $40 \mathrm{~g}$ soil collected between the circles (matrix). Overall, the soil (matrix and circles) contains a considerable amount of easily magnetised particles. The newly formed circle appears to have a higher amount of magnetised soil particles. This could be a consequence of the hydrocarbon seep providing for a greater bacterial energy source resulting in an enhanced alteration of the magnetic minerals within the seep.

\subsection{Relationships between mima mounds ("heuweltjies") and fairy circles}

The fairy circles have been linked to the mima-like mounds of the Northern and Western Cape in South Africa (Albrecht et al., 2001). The circles are regarded as the northern counterpart of these unusual earth mounds (Van Rooyen et al., 2004). It is generally thought that mima mounds are fossil features of biogenic origin and were produced by termites (Potts et al., 2009). Berg (1990) proposed that mima mounds were formed as a result of seismic activity (Moore and Picker, 1991). The distribution of earth mounds in the Western Cape coincides with an area of increased natural seismic hazard (Moore and Picker, 1991). However, Moore and Picker (1991) stated that the earth mounds have an internal stratification that indicates progressive growth by deposition of successive sand layers over a considerable period of time and not in a single event required by the seismic hypothesis. The soils of heuweltjies relative to surrounding soils are finer textured, more alkaline and have better water holding capacity that favour a very different community of plants (Desmet, 2007). According to Turner (2003) water retention in the fossil heuweltjie soil is enhanced permanently by an impermeable calcareous basement layer at depths of 2-3 $\mathrm{m}$, a consequence of calcite deposition from biogenic production of methane by bacteria in the intestines of termites. The soil chemistry of the mounds differs significantly from surrounding soils with enrichments in $\mathrm{Ca}, \mathrm{Mg}, \mathrm{K}, \mathrm{P}$ and $\mathrm{N}$ (Moore and Picker, 1991).

Hydrocarbon-induced topography is often characterised by conical or volcano-like forms, carbonate crusts, slabs, mounds or chimneys and pock mark-like features (Keller et al., 2007). Conical 

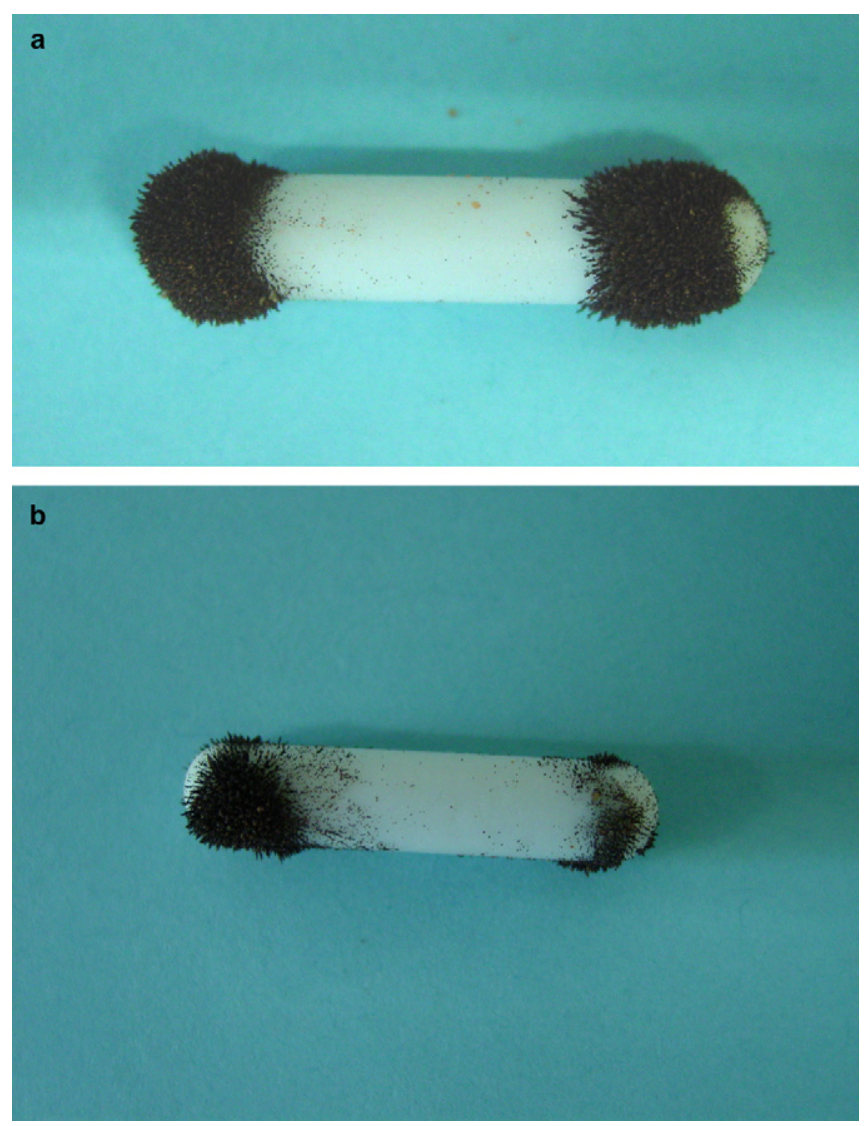

Fig. 6. (a) Magnetic stir bar with magnetic soil particles accumulated from $40 \mathrm{~g}$ soil collected from a circular patch of dead and yellowed vegetation. See Section 3.4 for details. (b) Magnetic stir bar with magnetic soil particles accumulated from $40 \mathrm{~g}$ soil collected between the circles (matrix 1.3). See Section 3.4 for details.

mounds may have a small central crater (Keller et al., 2007). Moore and Picker (1991) reported that the majority of earth mounds in the Clanwilliam district (South Africa) displayed a central depression. Schwarz (1906) described natural mounds in the Worcester area (South Africa) as "hillocks with slopes of varying angles and often as acute as a volcanic cone" and mounds in Malmesbury (South Africa) are described as "usually have a depression in the centre". Dietz (1945) described mima mounds related to barren soil circles in the Gulf Coastal Plain (oil/gas heartland) in the United States of America as such "Commonly associated with the mounds are circular patches of sand which are commonly referred to locally as "sinks" or "slick spots". No vegetation grows upon these sandy spots and consequently they appear as prominent white scars from the air". Albrecht et al. (2001) reported a remarkably close correlation between the $R$-value for spatial distribution of the barren fairy circles $(R=1.68)$ and the $R$-value recorded for the mima mounds ( $R=1.7$ ). Because mima mounds are believed to be fossil termitaria, this close correlation of $R$-values suggested that termites were also involved in the fairy circle phenomenon.

Potts et al. (2009) reported calcite content values of 23.2-65.2\% for on-mound samples collected from a mound near Worcester, South Africa. No calcite was detected for off-mound samples. The authors pointed out that the calcite content for on-mound samples show that the calcrete is a mound-associated phenomenon, as offmound samples contained no traces of calcite. Their conclusion was that calcrete formation in the mound stopped 22,000 years ago and since then the local climatic conditions surrounding the mounds have not been suitable for calcrete formation. Of particular interest pertaining to calcite detected in-mound, but not off-mound, is that hydrocarbon-induced alteration in a geochemical seep precipitates calcite $\left(\mathrm{CaCO}_{3}\right)$ (Schumacher, 1996). Mineral alteration related to hydrocarbon seepage can result in enrichment in carbonates with a concentration of calcium and secondary enrichment in calcite around the edge of the seep (Van der Meer et al., 2002). Seeprelated carbonates are generally patchy and complex with an irregular network of fractures and cavities present (Cavagna et al., 1999). Moore and Picker (1991) described the basal portions of the mounds as highly calcified and the calcification was patchy. In view of this, the near-surface slab of calcite associated with the fossil heuweltjies described by Turner (2003) may, instead, have derived from a geochemical source and not, as was suggested by the author, from termites.

It is the opinion of Becker (2007) that the foraging behaviour of harvester ants and harvester termites are the prime causal factor for the development of fairy circles. However, the author reported that specific conditions need to exist in order for fairy circles to develop, and even when these conditions are met, harvesting activity does not necessarily result in the development of a fairy circle. The results of Jankowitz et al.'s (2008) in situ study cannot be explained by termites or ants consuming plant material, nor can it be explained by self-organised vegetation pattern formation as causal factors for the development of fairy circles, but it can be interpreted as support for our theory of episodic air displacement by natural gas and the residual effect of traces of low volatility hydrocarbons in the circles. Grass plants growing in open containers inside the circle performed poorly, irrespective of the origin of the soil, while plants growing in sealed containers in the circle showed improved vitality (Jankowitz et al., 2008). A factor not considered by any of the studies reporting on the origin of the fairy circles is that termites are a source of methane which, potentially, could produce an anaerobic soil environment resulting in a zone of altered soil chemistry which may cause plant stress. However, the detection of unresolved complex mixtures and saturated alkanes $C_{12}-C_{20}$ are totally unrelated to termite activity.

Microseep migration is formed by the diffusion of gases passing through seemingly impenetrable barriers (Van der Meer et al., 2002). Colloidal size gas bubbles ascend through a network of interconnected groundwater filled "microfractures" (Jones et al., 2000; Mello et al., 1996; Van der Meer et al., 2000, 2002; Yang et al., 2000). The cross-sectional shape of the hydrocarbon leaking pattern has been labelled as "chimney effect", providing channels for seep migration (Van der Meer et al., 2002). Oxidation in the chimney above leaking hydrocarbon accumulations not only leads to the precipitation of carbonates (e.g. calcite) but also to a concentration of calcium with secondary enrichment of calcite around the edge of the seep to form ring structures. The circular shape of the fairy circles correlates with the surface expression of a seep. Fairy circles may be associated with "chimneys" which may explain the perceived patterning distribution of the circles. The circles seem as if uniformly spread, but this is not necessarily so, because the two newly formed circles were adjoining each other.

Our results show that the fairy circles are a surface expression of geochemical seepage. If a causal link exists between circles and fossil mounds, as it is indeed suggested by the close correlation between the two phenomena, then mima mounds are not exclusively fossilised termite nests. Instead, the mounds may be fossilised geochemical seep relics. The significantly different soil chemistry of the mounds compared to surrounding soil suggests correlation with the hydrocarbon-induced alteration of soils in a geochemical seep. The particle size and sorting effect in the mound, mudflow event, mound soil enrichment, the cessation of calcite formation in-mound and the absence of calcite off-mound, together with the fact that mound formation did not take place in a single event, but rather, over a considerable period of time may be 
explained in terms of a fossil hydrocarbon seep. The hypothesis that mounds may be fossil seep relics, of course, needs investigation.

\section{Conclusions}

We propose the origin of the fairy circle to be of a geological nature. Our results show a microseepage of gases and hydrocarbons which manifests at the surface as a geobotanical anomaly of barren circles and circles of altered vegetation. Seepage may be minor venting and an anomaly does therefore not necessarily imply an economic hydrocarbon accumulation. The evidence of geochemical seepage is provided by:

- Geobotanical anomalies. Elevated natural gas concentrations in soil show as geobotanical anomalies of circular patches of stressed and dead vegetation and circles of barren soil.

- The presence of natural gases. Measured amounts of the nonhydrocarbon gas, CO (indicator of natural gas), do not fully account for the relatively small displacement of $\mathrm{O}_{2}$. Additional gases are therefore present in the seep.

- Microbiological anomalies. Alkenes, the microbiological degradation product of alkanes, were detected. Higher levels of alkenes were detected in soil collected from inside barren circles when compared to the relatively lower levels of alkenes detected in soil collected from between the barren circles (matrix). The relatively higher levels of alkenes detected inside the circles are indicative of the presence of a richer microbial food source inside the circles. The relatively lower levels of alkenes detected in soil collected from between the barren circles (matrix) are indicative of the presence of a less abundant microbial food source in the matrix.

- Anomalous hydrocarbons. Saturated alkanes were detected in both of the newly formed circles. An alkane/alkene ratio of $>1$ indicates an active seep. The two newly formed circles had ratios of 7 and 72, suggesting very active seepage.

- Magnetic susceptibility. The soil exhibits strong magnetic properties.

The solventless method of extraction of hydrocarbons from soil was simple and successful and can be useful for the sampling of small sized soil samples.

\section{Acknowledgements}

We thank Prof N. Grobbelaar for suggesting many years ago that gases should be analysed, NamibRand Nature Reserve in Namibia for granting an entry permit to the park, Namibian Ministry of Environment and Tourism for a research permit, Dr Willem Jankowitz for assistance with obtaining the permit at the ministry, $\mathrm{Dr}$ Noel van Rooyen of Ekotrust and Dr Sieglinde Bauermeister of the Department of Chemistry, University of Pretoria, for assisting during field sampling.

\section{References}

Abrams, M., 2005. Significance of hydrocarbon seepage relative to petroleum generation and entrapment. Marine and Petroleum Geology 22, 457-477.

Albrecht, C.F., Joubert, J.J., De Rycke, P.H., 2001. Origin of the enigmatic, circular, barren patches ('Fairy Rings') of the pro-Namib. South African Journal of Science 97, 23-27.

Becker, T., 2007. The phenomenon of fairy circles in Kaokoland (NW Namibia). Basic and Applied Dryland Research 1 (2), 121-137.

Borgogno, F., D'Odorico, P., Laio, F., Ridolfi, L., 2009. Mathematical models of vegetation pattern formation in ecohydrology. Reviews of Geophysics 47, 1-36.

Carte Blanche [online]. Available: http://www.mnet.co.za/Mnet/Shows/carteblanche/ story.asp? Id=2603 (accessed 06.09.10)
Cavagna, S., Clari, P., Martire, L., 1999. The role of bacteria in the formation of cold seep carbonates: geological evidence from Monferrato (Tertiary, NW Italy). Sedimentary Geology 126, 253-270.

Desmet, P.G., 2007. Namaqualand - a brief overview of the physical and floristic environment. Journal of Arid Environments 70, 570-587.

De Vita, V., 2006. African Desert Has Its Own X-files [online] Available: http://www. iol.co.za/index.php?from $=$ rss_Travel\&set_id $=14 \&$ click_id=0\&art id $=$ vn20060729094938616C147804 (accessed 07.09.10).

Dietz, R.S., 1945. The small mounds of the Gulf Coastal Plain. Science 102 (2658) 596-597.

Eicker, A., Theron, G.K., Grobbelaar, N., 1982. 'n Mikrobiologiese studie van "kaal kolle" in die Giribesvlakte van Kaokoland, S.W.A.-Namibië. South African Journal of Botany 1, 69-74.

Eldmore, R.D., Engel, M.H., Crawford, L., Nick, K., Imbus, S., Sofer, Z., 1987. Evidence for a relationship between hydrocarbons and authigenic magnetite. Nature 325 428-430.

Grossi, V., Cravo-Laureau, C., Guyoneaud, R., Ranchou-Peyruse, A., Hirschler-Réa, A. 2008. Metabolism of $n$-alkanes by anaerobic bacteria: a summary. Organic Geochemistry 9, 1197-1203.

Hamamura, N., Olson, S.H., Ward, D.M., Inskeep, W.P., 2005. Diversity and functional analysis of bacterial communities associated with natural hydrocarbon seeps in acidic soils at Rainbow Springs, Yellowstone National Park. Applied and Environmental Microbiology, 5943-5950.

Harbert, W., Jones, V.T., Izzo, J., Anderson, T.H., 2006. Analysis of light hydrocarbons in soil gases, Lost River region, West Virginia: relation to stratigraphy and geological structures. AAPG Bulletin 90, 715-734.

Ingham, E.R.. Soil fungi [online]. Available: http://soils.usda.gov/sqi/concepts/soil biology/biology.html (Chapter 4) (accessed 01.03.10).

Jankowitz, W.J., Van Rooyen, M.W., Shaw, D., Kaumba, J.S., Van Rooyen, N., 2008 Mysterious circles in the Namib Desert. South African Journal of Botany 74 $332-334$.

Jones, V.T., Matthews, M.D., Richers, D.M., 2000. Light hydrocarbons for petroleum and gas prospecting. In: Hale, M., Govett, G.J.S. (Eds.), Handbook of Exploration Geochemistry, vol. 7. Elsevier Science Publishers, Amsterdam, pp. 133-212 (Chapter 5).

Joubert, A., 2008. Investigation on Selected Biotic and Abiotic Factors in the Maintenance of the "Fairy Circles" (Barren Patches) of Southern Africa. M.Sc dissertation, University of Pretoria, Pretoria, South Africa.

Keller, E.A., Duffy, M., Kennett, J.P., Hill, T., 2007. Tectonic geomorphology and hydrocarbon induced topography of the Mid-Channel Anticline, Santa Barbara Basin, California. Geomorphology 89, 274-286.

Liu, Q., Liu, Q., Chan, L., Yang, T., Xia, X., Cheng, T., 2006. Magnetic enhancement caused by hydrocarbon migration in the Mawangmiao oil field, Jianghan Basin China. Journal of Petroleum Science and Engineering 53, 25-33.

Lovegrove, B., 1993. The Living Deserts of Southern Africa. Fernwood Press, Vlaeberg.

Macgregor, D.S., 1993. Relationships between seepage, tectonics and subsurface petroleum reserves. Marine and Petroleum Geology 10, 606-619.

Mello, M.R., Babinski, N.A., Gonçalves, F.T., Miranda, F.P., 1996. Hydrocarbon prospecting in the Amazon rain forest: application of surface geochemical, microbiological, and remote sensing methods. In: Schumacher, D., Abrams, M.A (Eds.), Hydrocarbon Migration and Its Near-surface Expression. AAPG Memoir 66, 401-411.

Moll, E.J., 1994. The origin and distribution of fairy rings in Namibia. In: Seyani, J.H. Chikuni, A.C. (Eds.), Proceedings of the 13th Plenary Meeting AETFAT, Malawi, pp. 1203-1209.

Monson, L.M., Shurr, G.W., 2003. Assessment of hydrocarbon seepage on Fort Peck Reservation, Northeast Montana: a comparison of surface exploration techniques. AAPG Annual Convention, Salt Lake City, Utah.

Moore, J.M., Picker, M.D., 1991. Heuweltjies (earth mounds) in the Clanwilliam district, Cape Province, South Africa: 4000-year-old termite nests. Oecologia 86 424-432.

Morikawa, M., Kanemoto, M., Imanaka, T., 1996. Biological oxidation of alkane to alkene under anaerobic conditions. Journal of Fermentation and Bioengineering 82, 309-311.

Noomen, M.F., Skidmore, A.K., Van der Meer, F.D., 2003. Detecting the influence of gas seepage on vegetation, using hyperspectral remote sensing. In: Third EARSeL Workshop on Imaging Spectroscopy, Herrsching.

Osuji, L. Antia, B.S., 2005. Geochemical implication of some chemical fossils as indicators of petroleum source rocks. Journal of Applied Sciences and Environmental Management 9, 45-49.

Potts, A.J., Midgley, J.J., Harris, C., 2009. Stable isotope and ${ }^{14} \mathrm{C}$ study of biogenic calcrete in a termite mound, Western Cape, South Africa, and its paleoenvironmental significance. Quaternary Research 72, 258-264.

Rangel, A., Katz, B., Ramirez, E., Vaz dos Santos Neto, E., 2003. Alternative interpretations as to the origin of the hydrocarbons of the Guajira Basin, Colombia. Marine and Petroleum Geology 20, 129-139.

Rietkerk, M., Dekker, S.C., De Ruiter, P.C., Van de Koppel, J., 2004. Self-organised patchiness and catastrophic shifts in ecosystems. Science 305, 1926-1929.

Schumacher, D., 1996. Hydrocarbon-induced alteration of soils and sediments. In: Schumacher, D., Abrams, M.A. (Eds.), Hydrocarbon Migration and Its Nearsurface Expression. AAPG Memoir 66, 71-89.

Schumacher, D., LeSchack, L.A., 2002. Surface exploration case histories, applications of geochemistry, magnetics, and remote sensing. In: AAPG Studies in Geology, No. 48. AAPG, Tulsa, OK, USA, pp. 1-486. 
Schumacher, D., Foote, R.S., 2006. Seepage-induced magnetic anomalies associated with oil and gas fields: onshore and offshore examples. In: CSPG-CSEG-CWLS Convention, Canada.

Schwarz, E.H.L., 1906. Natural mounds in Cape Colony. The Geographical Journal 27 (1), 67-69.

Smith, K.L., Steven, M.D., Colls, J.J., 2004. Use of hyperspectral derivative ratios in the red-edge region to identify plant stress responses to gas leaks. Remote Sensing of Environment 92, 207-217.

Stone, V.C.A., Fairhead, J.D., Oterdoom, W.H., 2004. Micromagnetic seep detection in the Sudan. The Leading Edge 23 (8), 734-737.

Summons, R.E., Hope, J.M., Swart, R., Walter, M.R., 2008. Origin of Nama Basin bitumen seeps: petroleum derived from a Permian lacustrine source rock traversing southwestern Gondwana. Organic Geochemistry 39, 589-607.

Theron, G.K., 1979. Die verskynsel van kaal kolle in Kaokoland, SuidWes-Afrika. Journal of the South African Biological Society 20, 43-53.

Torti, S.D., Coley, P.D., Janos, D.P., 1997. Vesicular-arbuscular mycorrhizae in two tropical monodominant trees. Journal of Tropical Ecology 13 (4), 623-629.

Turner, J.S., 2003. Trace fossils and extended organisms: a physiological perspective. Palaeogeography, Palaeoclimatology, Palaeoecology 192, 15-31.
Van der Meer, F., Van Dijk, P., Kroonenberg, S., Yang, H., Lang, H., 2000. Hyperspectral hydrocarbon microseepage detection and monitoring: potentials and limitations. In: Second EARSeL Workshop on Imaging Spectroscopy, Enschede, The Netherlands.

Van der Meer, F., Van Dijk, P., Van der Werff, H., Yang, H., 2002. Remote sensing and petroleum seepage: a review and case study. Terra Nova 14 (1), 1-17.

Van Rooyen, M.W., Theron, G.K., Van Rooyen, N., Jankowitz, W.J., Matthews, W.S., 2004. Mysterious circles in the Namib Desert: review of hypotheses on their origin. Journal of Arid Environments 57, 467-485.

Walden, J., White, K.H., Kilcoyne, S.H., Bentley, P.M., 1999. Analyses of iron oxide assemblages within Namib dune sediments using high field remanence measurements (9 T) and Mössbauer analysis. Journal of Quaternary Science 15, 185-195.

Xu, D.-Q., Ni, G.-Q., Jiang, L.-L., Shen, Y.-T., Li, T., Ge, S.-L., Shu, X.-B., 2008. Exploring for natural gas using reflectance spectra of surface soils. Space Research 41, $1800-1817$.

Yang, H., Meer, F.V.D., Zhang, J., Kroonenberg, S.B., 2000. Direct detection of onshore hydrocarbon microseepages by remote sensing techniques. Remote Sensing Reviews 18, 1-18. 